\title{
Quantification of yield loss to pineapple heart rot disease on pineapple cultivars in Uganda
}

\author{
Oculi Jasper. ${ }^{1 *}$, Bua Bosco. ${ }^{1}$ and Ocwa Akasaire ${ }^{1}$ \\ Department of Agriculture, Kyambogo University, P.O Box 1, Kyambogo, Uganda \\ Corresponding author:jasperbenedict@gmail.com
}

Key words: Yield Loss, pineapple Cultivar, Pineapple heart rot, Metalaxyl and Fosetyl Al

Publication date 31/07/2019, http://www.m.elewa.org/JAPS

\section{$1 \quad$ ABSTRACT}

Pineapple (Ananas comosus L. Merr) is an important fruit crop in Uganda. Pineapple production in Uganda is devastated by pineapple heart rot disease (PHRD) which is associated with serious economic and yield losses. Therefore, this study quantified yield loss on five pineapple cultivars to pineapple heart rot disease in central Uganda. Five cultivars (Smooth Cayenne, Victoria, Sasilimu, MD-2 hybrid and Red Spanish) were tested for latent infection by planting the suckers in buckets containing 10 kilograms of sterile soil for four month. Disease free suckers, four month old, of average size from the five cultivars were planted in pots containing 10 kilograms of sterile clay-loam soil in the screen house in 2016/2017 in a completely randomized design (CRD). Treatments consisted of protected pots, un-protected pots and control pots respectively. Pineapple plants in the protected pots had their suckers dipped for three minutes in a solution of Metalaxyl (Active Ingredients: methoxyacetyl)-N-(2, 6-xylyl)-DL-alaninate $8 \%$ ) before planting and later sprayed with a solution of Fosetyl Al (Active Ingredients: Aluminum tris 80\%) using a backpack sprayer with Hardir flat spray nozzles three weeks after planting. Pineapple plants in the unprotected pots were not treated with any fungicide. The suckers in protected and unprotected pots were inoculated with $10^{8} \mathrm{ml}$ of zoospores using needle-mediated leaf base wound technique. Control pots were not inoculated. Data on pineapple heart rots caused by the pathogen was collected from all the pots and thus used to compute yield loss per cultivar. Data was analyzed usin analysis of variance (ANOVA) of the GenStat computer program $\left(15^{\text {th }}\right.$ edition). Pineapple heart rot disease $(P H R D)$ significantly $(P<0.001)$ reduced pineapple yield in the un-protected pots across all the five cultivars evaluated in both trial one and trial two. Metalaxyl (Ridomil) and Fosetyl Al treatment significantly $(\mathrm{P}<0.001)$ reduced yield losses in all the five cultivars used in the Protected pots in trial one and trial two respectively. The highest and lowest yield loss was recorded in cultivar Victoria and Smooth Cayenne respectively. PHRD can cause $100 \%$ yield loss. Metalaxyl (Ridomill) and Fosetyl $\mathrm{Al}$ is recommended for the control of PHRD in Uganda

\section{INTRODUCTION}

Pineapple (Ananas comosus L. Merr) is one of the most important plants in the family bromeliaceae (Bartholomew et al., 2003). Pineapple is ranked the third most important tropical fruit crop after banana and citrus in the world (Hassan et al., 2011; 2015). In Uganda, pineapple is commonly grown in the central region in the districts of Mukono, Kayunga, Luwero and Masaka (Bua et al., 2013; Ocwa et al.) Pineapple is one of the crops in the fruit sub sector that 
has been selected for export diversification and sustainable enhancement of household income in Uganda (UIA, 2015). As a result many farmers in most parts of the country have taken on pineapple production. According to Kwikiriza et al. (2016), 75\% of pineapple in Uganda worth US \$ 350,000 (Ugandan shillings $1,225,000,000)$ was exported in 2013/14. However, pineapple production is still below optimum because of a diversity of constraints (UIA, 2008). Pests and diseases, lack of improved pineapple production technologies and declining soil fertility are among the notable constraints (Bua et al., 2013). The major pineapple diseases reportedly causing decline in production includes pineapple heart rot diseaseand pineapple mealy bug wilt disease (PMBWD) (Bua et al., 2013, Agrios, 2005). Pineapple heart rot disease manifests as watersoaked tissue on the center most leaves surrounding the apical meristem, formation of brown streaks on lamina and in mesophyll tissues (Drenth and Sendall, 2004, James and Scot, 2015). Light brown exudates emerge from the blisters as leaves begin to rot (Shen et al., 2013) (Plate 1).

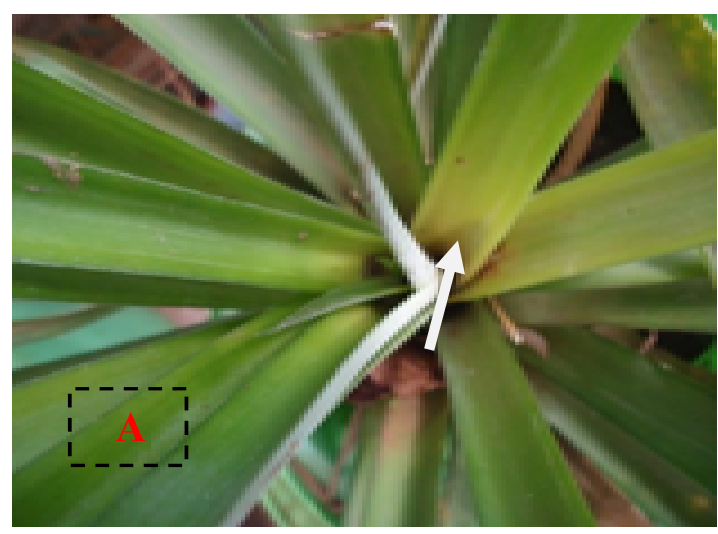

Plate 1. A=Pineapple plant three weeks after Inoculation with PHRD

Globally, PHRD is associated with Phytophthora cinnamomi and Phytophthora nicotianae (Rohrbach and Schenke, 1985; Rodriguez et al., 2015). In central Uganda, Phytophthora nicotianae was identified as the pathogen causing PHRD (Ocwa et al., 2017). This pathogen is highly pathogenic and devastating. However, pathogenicity and yield loss by Phytophthora

\section{MATERIALS AND METHODS}

3.1 Study area: The study was conducted from November 2015 to March 2017 in the screen house at the Department of Agriculture, Kyambogo University Kampala (1189 meters above sea level, $00^{\circ} 20^{\prime} 54^{\prime \prime} \mathrm{N}$, and $\left.32^{\circ} 37^{\prime} 49^{\prime \prime} \mathrm{E}\right)$. All the trials were repeated to generate first season and second season data.

3.2 Collection and preparation of planting materials: One hundred seventy (170) healthy pineapple suckers from the five cultivars (Smooth cayenne, Victoria, MD-2 hybrid, Red Spanish and

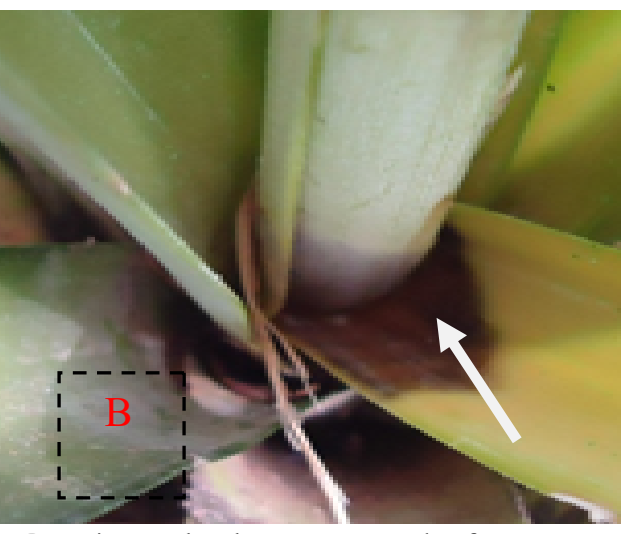

$\mathrm{B}=$ Pineapple plant one month after Inoculation with PHRD

nicotianae causing PHRD depends on the variety of pineapple. Currently, information on yield loss by PHRD on different pineapple cultivars in Uganda is limited. Therefore, the basis of this study was to assess yield loss on five common pineapple cultivars to PHRD in central Uganda.

Sasilimu) were purposively sampled from the districts of Masaka, Luwero, Mukono and Kayunga. The suckers were purposively sampled to avoid infected fields. Latent infection on the suckers was confirmed by planting the suckers in the pots filled with 10 kilograms of sterilized clay loam soil in the screen house for four months (Py et al., 1987). The plants were watered as and when necessary. Suckers that developed PHRD symptoms were discarded. The disease free suckers were subsequently used to establish trials in the screen house. 
3.3 Isolation of pineapple heart rot causal Phytophthora: One hundred twenty (120) symptomatic pineapple samples were collected in the month of November, 2015. The collected samples were packed in paper bags and taken to the laboratory for isolation of Phytophthora pathogen. Isolation of pineapple heart rot disease causal organisms was done using cornmeal agar amended with $10 \mathrm{mg}$ pimaricin, $250 \mathrm{mg}$ ampicillin, $10 \mathrm{mg}$ rifampicin, $\quad 10 \mathrm{mg} \quad$ benomyl, $\quad 25 \mathrm{mg}$ Pentachloronitrobenzene (PCNB) and 50mg hymexazol (PARBPH) as described by Drenth and Sendall (2001). The symptomatic pineapple leaves were washed under running water to eliminate soil. Five (5) $\mathrm{mm}$ pieces were cut off the disease lesions between healthy and diseased tissue of symptomatic pineapple. The cut tissue pieces were disinfested by immersion in a solution of $70 \%$ ethanol for 3 minutes rinsed three times with sterile distilled water and dried with sterile paper towels. The dried leaf fragments were placed on cornmeal agar (CMA) amended as described above (Drenth and Sendall 2001; Mounde et al., 2012; Rodriguez et al., 2015). The petri-plates were incubated at $25 \mathrm{oC}$ in the dark for 2-3 days (Drenth and Sendall 2001; Mbaka et al., 2010; Mounde et al., 2012). Pure cultures of Phytopthora isolate were obtained by sub-culturing hyphal tips on to freshly prepared corn meal agar (CMA) as described above for 2-3 days. Morphological characteristics of the isolates were assessed using Potato dextrose agar (PDA) and V8 media respectively to confirm the identity of the pathogen (Mounde et al., 2012).

\subsection{Inoculum preparation and} pathogenicity tests: Phytophthora isolates used for the study were induced to sporulate following the protocol described by Jeffers (2006). Zoospore release was induced by incubating agar plugs with sporangia in non-sterile soil extract solution (NSSES) at $40^{\circ} \mathrm{C}$ for 30 minutes to shock the sporangia. Isolates were later placed at room temperature for 10-20 minutes to burst the sporangia so as to release zoospores (Saadoun and Allagui, 2008). The zoospores were observed on a light microscope to confirm their presence, and subsequently, the number of zoospores was quantified using haemocytometer (Cabral, 1985; Matos, 2006;). The pathogenicity of Phytophthora isolates recovered from the infected pineapple leaves was confirmed by inoculating them on to two month old healthy MD2 pineapple plants using $10^{8} \mathrm{mls}$ of zoospores of PHRD causal pathogen using the needle-mediated leaf base wound technique (Rodriquez et al. 2002; Shen et al., 2013).

3.5 Experimental design: The experiment was arranged in a completely randomized design (CRD) with three replications. Treatments consisted of five pineapple cultivars in protected pots, five pineapple cultivars in un-protected pots and five pineapple cultivars in control pots respectively. The five Pineapple cultivars in the protected pots had their suckers dipped (completely submerged) for three minutes in a solution of Metalaxyl 8\% with active ingredient Methyl N-(methoxyacetyl)-N-(2, 6-xylyl)-DL-alaninate ( $10 \mathrm{~g} \mathrm{~L}-1$. of water) before planting and later sprayed with a solution of Fosetyl $\mathrm{Al}$ with active Ingredients: Aluminum tris 80\% (10 g L-1. of water) using a backpack sprayer with Hardir flat spray nozzles three weeks after planting, thereafter, monthly spray with Fosetyl Al was maintained (Joy and Sindhu 2012). Five pineapple cultivars in the un-protected pots were not treated with any fungicide. Actively growing pineapple plants in both protected and un-protected pots, approximately six months old were then inoculated with $108 \mathrm{mls}$ of the zoospores of PHRD causal pathogen using the needle-mediated leaf base wound technique (Rodriquez et al. 2002). Control plots were inoculated with $5 \mathrm{mls}$ of sterile distilled water.

3.6 Data collection: The relative losses in pineapple yield were determined as a percentage of that of the protected pots. The formula of Teshome and Tegegn (2017) was adopted with modification to estimate yield loss per cultivar in each treatment pots:

$$
R L(\%)=\frac{\left(\mathrm{Y}_{1}-\mathrm{Y}_{2}\right)}{\mathrm{V}}>
$$

Where;

$\mathrm{RL} \%=$ percentage of relative loss (reduction of the yield)

$\mathrm{Y} 1$ = mean yield on the protected pots (pots with fungicide treatment)

$\mathrm{Y} 2=$ mean yield on unprotected pots (pots without fungicide)

3.7 Data Analysis: Analysis of variance (ANOVA) of the GenStat computer program (15 th edition) was used to test for the significance of yield loss across the different cultivars used in the experiment. Differences in means were separated using Least Significant Difference (LSD) test at 5\% probability level. 


\section{$4 \quad$ RESULTS}

The highest and lowest yield losses in unprotected pots of $100 \%$ and $93 \%$ were recorded in Victoria and Smooth cayenne in trial one. MD2 hybrid, red Spanish and Sasilimu recorded 99\%, 98\% and 96\% respectively. Additionally, the highest and lowest yield losses in protected pots of $7 \%$ and $0 \%$ were recorded in smooth Cayenne and Victoria. MD2

hybrid, red Spanish and Sasilimu recorded 1\%, 2\% and $4 \%$ respectively in protected pots, trial one. No yield loss was registered in all the five pineapple cultivars planted in control pots in trial one. PHRD increased progressively in all the five cultivars reaching peak infection at week five after inoculation (Table 1 and Figure 1,2).

Table.1: Yield loss per variety, Season 1 at an evaluation done at Kyambogo University screen house, 2016

\begin{tabular}{l|l|l|l}
\hline VARIETY & $\begin{array}{l}\text { YIELD LOSS IN } \\
\text { PROTECTED POTS }\end{array}$ & CONTROL POTS & $\begin{array}{l}\text { YIELD LOSS IN } \\
\text { UNPROTECTED } \\
\text { POTS }\end{array}$ \\
\hline MD-2HYBRID & 1 & 0 & 99 \\
RED SPANISH & 2 & 0 & 98 \\
SASILIMU & 4 & 0 & 96 \\
SMOOTH & 7 & 0 & 93 \\
CAYENNE & & 0 & 100 \\
VICTORIA & 0 & & $\mathbf{3 1 . 3}$ \\
MEANS & & & $\mathbf{3 3 . 1 4}$ \\
LSD (5\%) & &
\end{tabular}

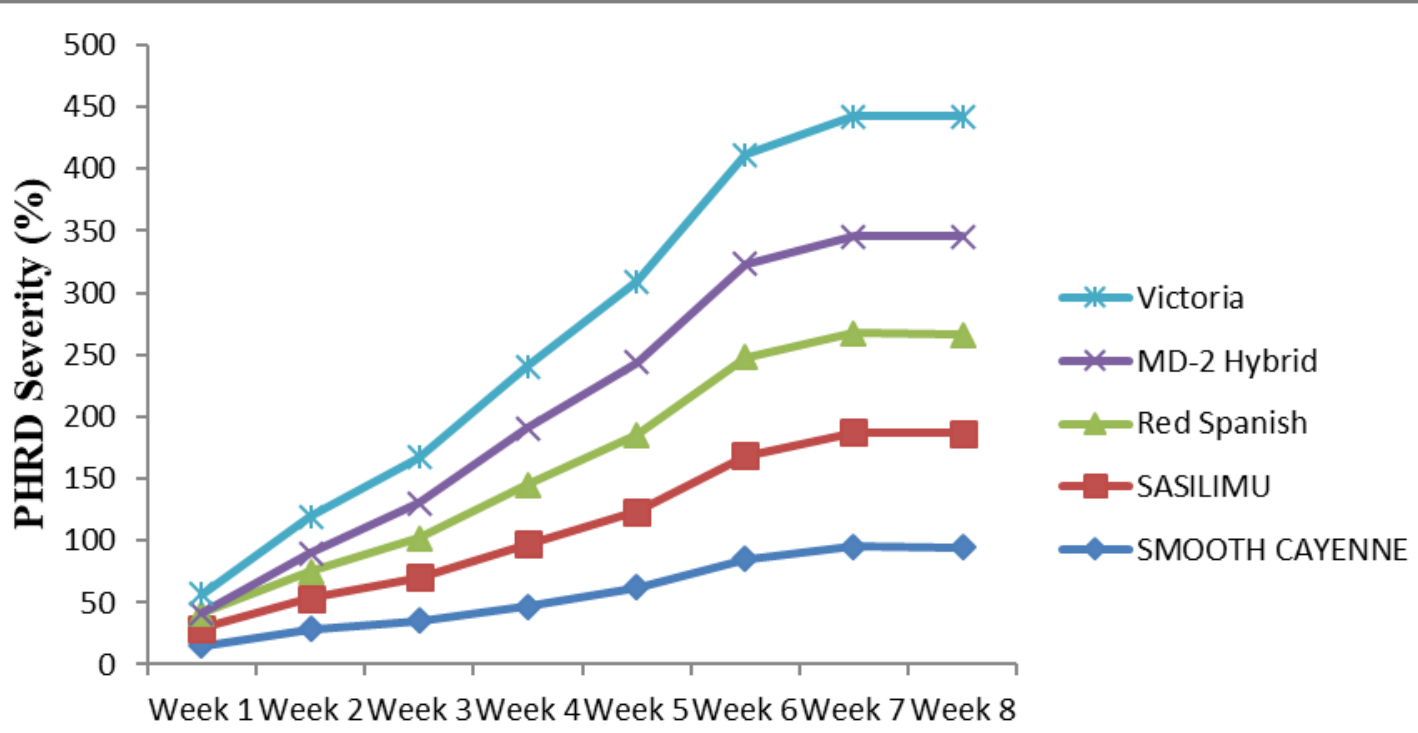

Weeks

Figure.1: Disease Severity on 5 pineapple cultivars, trial one in an evaluation at Kyambogo University screen house, 2016 


\begin{tabular}{ll}
\hline Oculi et al., $2019 \quad \begin{array}{l}\text { Journal of Animal \& Plant Sciences (J.Anim.Plant Sci. ISSN 2071-7024) } \\
\text { Vol.41 (1): 6784-6792. https://doi.org/10.35759/JAnmPISci.v41-1.5 }\end{array}$ \\
\hline
\end{tabular}

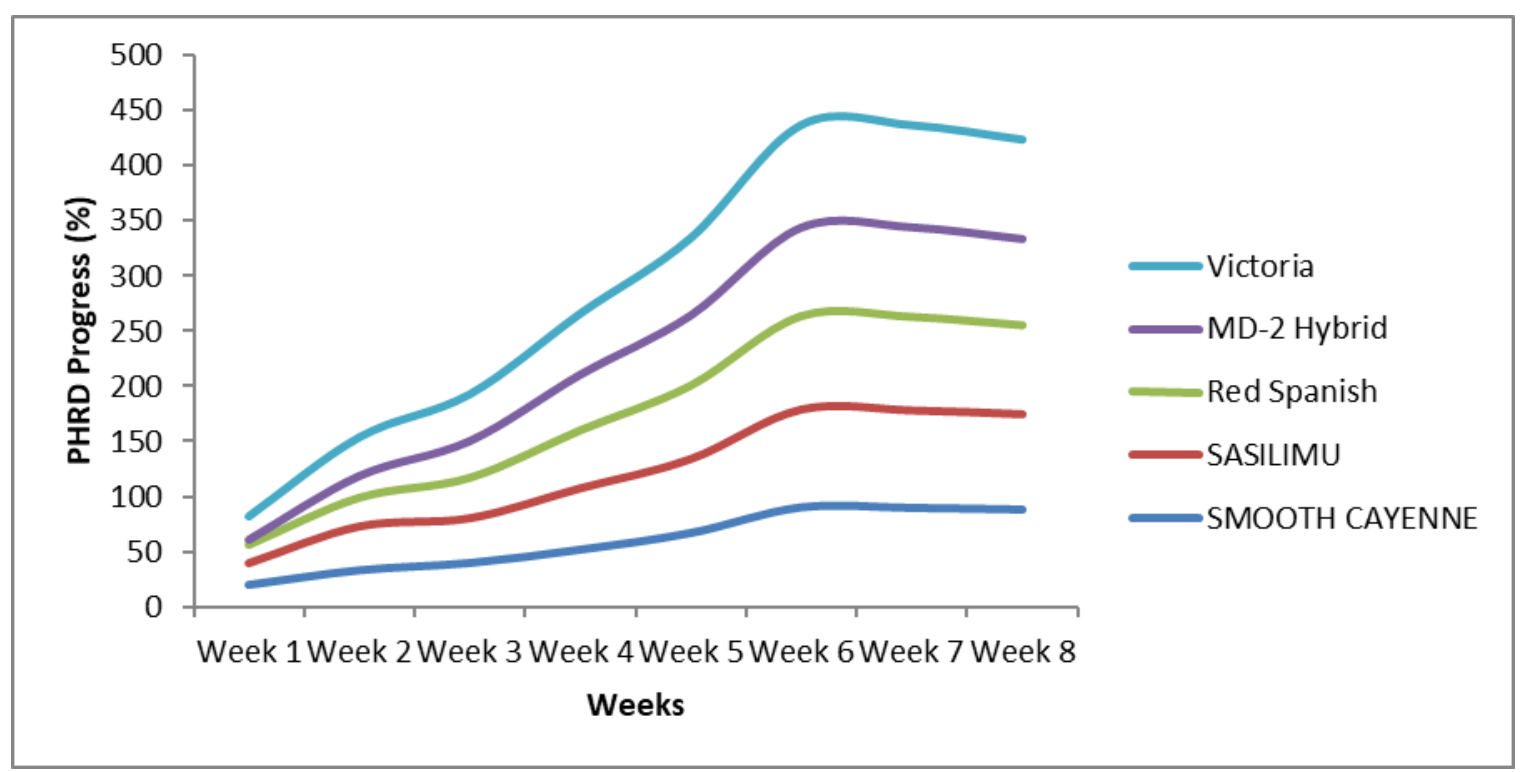

Figure.2: Disease progress on 5 pineapple cultivars, trial one in an evaluation at Kyambogo University screen house, 2016

Similar trend was observed in trial two with cultivar Victoria and Smooth cayenne recording the highest yield losses in unprotected pots. Sasilimu and Smooth cayenne recorded yield loss of $1 \%$ and $3 \%$ respectively. However, MD2 hybrid, red Spanish and Victoria did not register any loss in yield in protected pots. Similarly, no yield loss was recorded in all the five pineapple cultivars planted in control pots in second trial (Table 2, Figure 3 and 4). Generally, all the pineapple cultivars planted in unprotected pots recorded higher losses in yield although protected pots recorded very small yield losses in both trial one and two. PHRD progressively increased over time in all cultivars for both trial one and trial two (Figure 2 and 4).

Table.2: Yield loss per variety, Season 2 at an evaluation done at Kyambogo University screen house, 2017

\begin{tabular}{l|c|c|c}
\hline VARIETY & $\begin{array}{l}\text { YIELD LOSS IN } \\
\text { PROTECTED } \\
\text { PLOT }\end{array}$ & $\begin{array}{l}\text { CONTROL PLOT } \\
\text { YIELD LOSS IN } \\
\text { UNPROTECTED } \\
\text { PLOT }\end{array}$ \\
\hline MD-2HYBRID & 0 & 0 & 100 \\
RED SPANISH & 0 & 0 & 100 \\
SASILIMU & 1 & 0 & 99 \\
SMOOTH & 3 & 0 & 97 \\
CAYENNE & 0 & 0 & 100 \\
VICTORIA & & & $\mathbf{9 9 . 1 9}$ \\
MEANS & & & $\mathbf{2 . 1 1 0}$ \\
LSD (5\%) & & & \\
\hline
\end{tabular}




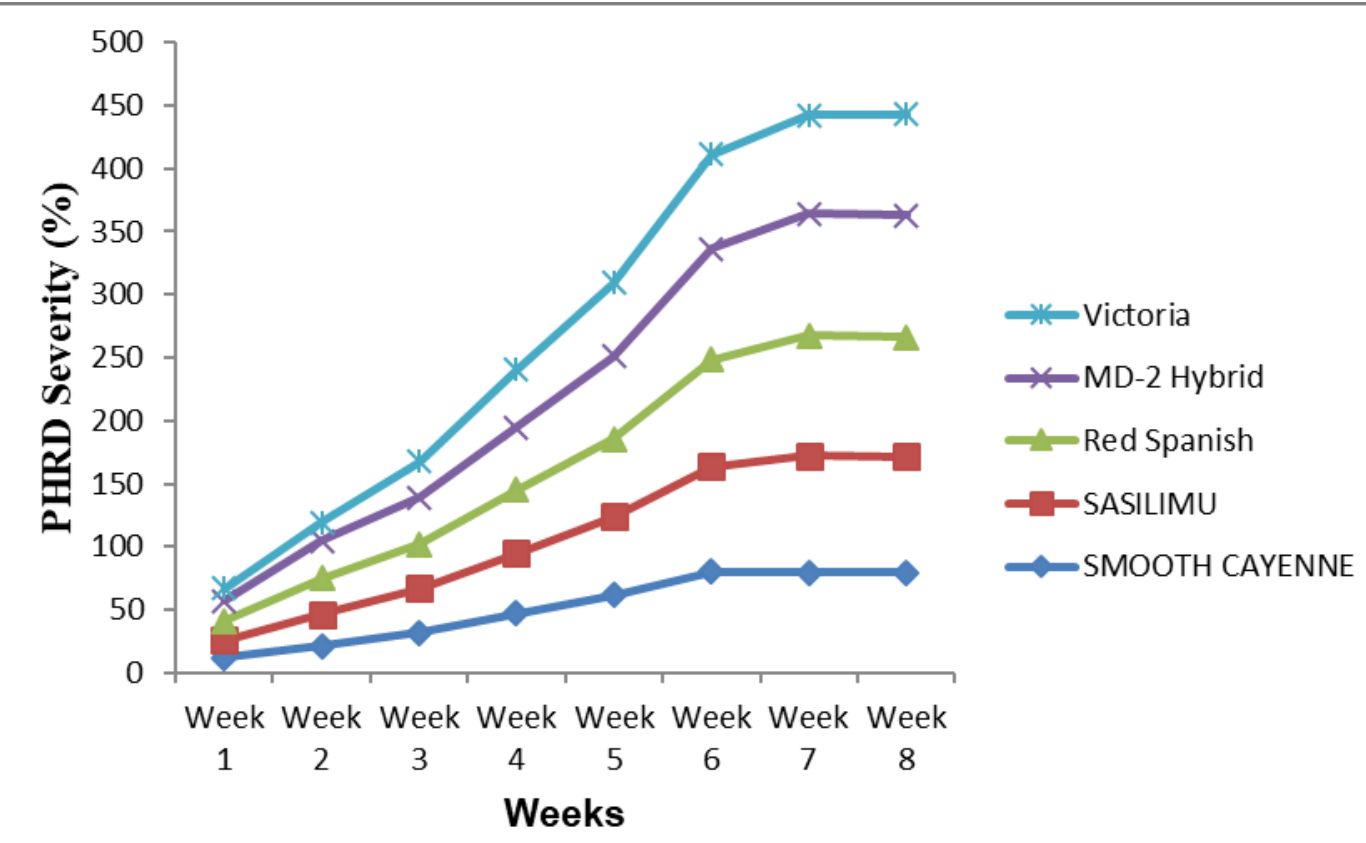

Figure.3: Disease Severity on 5 pineapple cultivars, trial two in an evaluation at Kyambogo University screen house, 2017

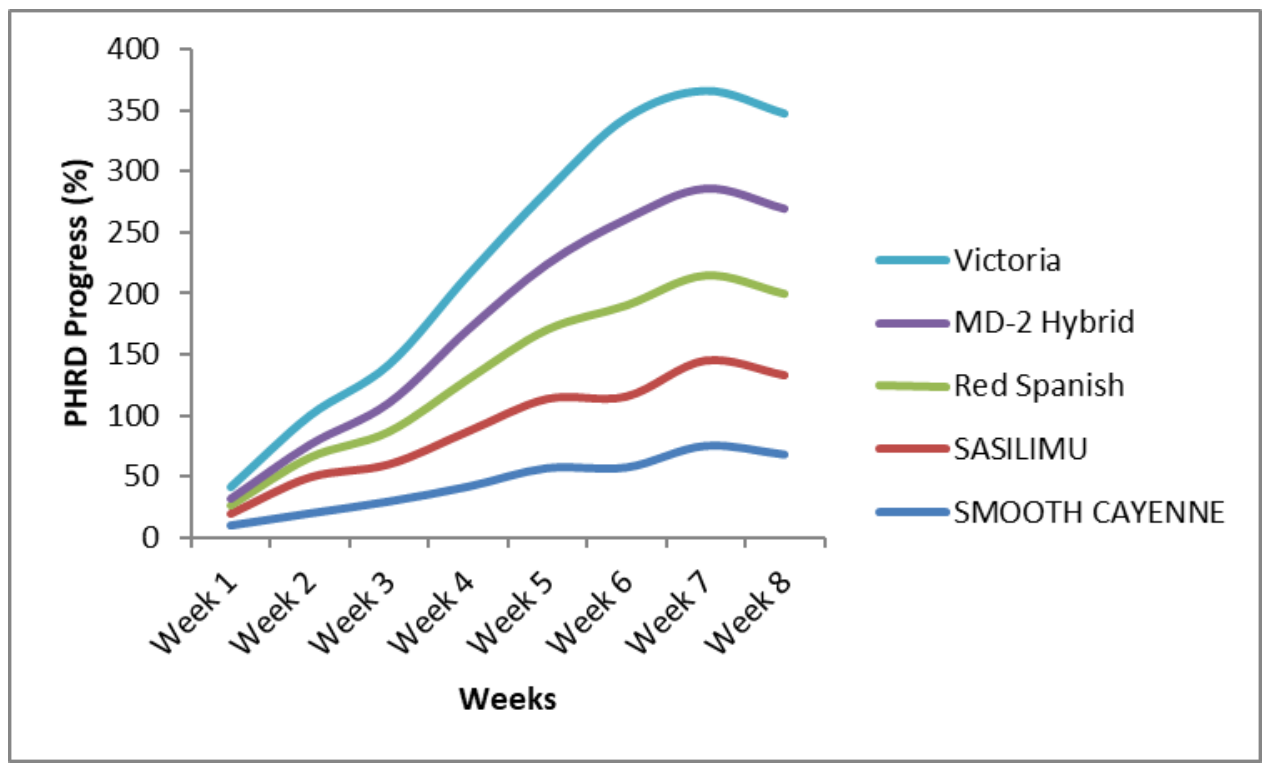

Figure.4: Disease progress on 5 pineapple cultivars, trial two in an evaluation at Kyambogo University screen house, 2017

Overall, Metalaxyl (Ridomill) and Fosetyl Al treatment significantly $(\mathrm{P}<0.001)$ reduced yield losses in all the five cultivars used in the Protected pots in trial one and trial two respectively.
Additionally, PHRD significantly $(\mathrm{P}<0.001)$ reduced pineapple yield in the un-protected pots across all the five cultivars evaluated in both trial one and trial two. 


\section{DISCUSSION}

The results of this study have shown significant variation in yield losses caused by PHRD under different treatments in trials one. Yield loss in protected pots was not significant. No yield losses were recorded in control pots across all the cultivars evaluated. Additionally, cultivars Victoria and Smooth cayenne recorded the highest and lowest yield losses of $99.7 \%$ and $90.2 \%$ respectively in unprotected pots. However, cultivar MD-2 hybrid, red Spanish and Sasilimu recorded yield losses of $96.8 \%, 95.4 \%$ and $94.4 \%$ respectively. In trial two however, Victoria, MD-2 hybrid, red Spanish, Sasilimu and smooth cayenne recorded yield loses of 99.7, 99.4, 99.3, 98.9, and 94.5 respectively. The result from this study indicates that PHRD is causing highly significant losses in pineapple yield. The findings by Drenth and Sendall, (2004), is consistent with the result of this study, in their report, Phytophthora heart rot disease caused by Phytophthora cinammomi, P. nicotinae and P. palmivora is the most destructive disease of pineapple worldwide. The report indicated that annually, the disease results in estimated losses in pineapple production in Asia, Africa and Brazil totalling to about 450,000 tons worth 423 million United States dollars in revenue. Additionally, report by FAO (2007) in Hawaii indicated that Pineapple production in 2007 dropped from 212,000 tons in 2005 to 172,500 tons in 2007 due to PHRD. Studies conducted by Darwis (1992) further validate the result of this study. In his findings, Darwis (1992) reported that almost all areas planted with pineapple in Indonesia have suffered serious damage from heart rot with losses in excess of $80 \%$. In fact, Darwis (1992) further pointed that in some areas, stand losses of $100 \%$ was recorded on pineapple, this compares very well with the findings from this study. Crop losses of $40-50 \%$ due to root rot have been recorded in other areas (Erwin and Ribeiro, 1996). For example, In Vietnam they were higher by $50-65 \%$ due to inexperience in managing root and heart rot by farmers coupled with high ground water tables and the use of susceptible varieties, this is consistent with our results in which pineapple suckers were planted in buckets and watered regularly. A study conducted by Drenth and Sendall, (2004) further reinforces our findings. In their study in wet tropical areas of South Asia, the yield loss was above the acceptable threshold per year. This was attributed to extensive monsoonal wet periods which favour disease developments. Additionally, in China, the incidence of PHRD ranged from 25-30\% (Shen et al., 2013). This represented significant loss in yield as infected plants collapse and dies. Losses from PHRD can be severe in poorly drained fields. Plants on even relatively well drained soils can be affected during prolonged wet weather. This is because the zoospores of Phytophthora heart rot disease pathogen move about freely in free water around the pineapple roots causing severe damage (Drenth and Sendall , 2004; Joy \& Sindhu 2012). The low losses in yields recorded on plots treated with Fosetyl $\mathrm{Al}$ and metalaxyl (Ridomill) in these trials are in agreement with the findings of Farih et al, (1981) who found that high concentration of the two fungicides of up to $1 \mathrm{~g} / \mathrm{L}$ resulted in effective control of P.cinamomi, P.parasitica and P. citropthora According to Rohrbach and Shenck (1985), both fungicides have been reported to control heart rot on Pineapple in other countries. When applied either as a pre-plant dip on vegetative seed material or as a post plant spray, Fosetyl $\mathrm{Al}$ reduced mortality caused by heart rot and has been recommended for the control of these diseases (Pegg, 1977). Control of PHRD by spraying fungicides from the early stages of plant development until flower initiation is largely used (Matos et al., 2009). Joy and Sindhu (2012) empathized the use of systemic fungicides to reduce heart rot. In their findings, the control program should start with the treatment of planting material before planting. After planting, drenching or spraying with registered fungicides at recommended rates and intervals is necessary to control yield losses. This is consistent with the result of this finding where pots treated with metalaxyl (Ridomill) as pre-plant dip and later sprayed with Fosetyl Al, 3 weeks after planting did not register any significant yield losses in both trials.

\section{CONCLUSION AND RECOMMENDATION}

Yield loss assessment conducted at Kyambogo University screen house indicated that PHRD causes highly significant losses in pineapple yield on all the cultivars assessed. This is because a greater percentage of the plants in pots that were not protected by fungicide collapsed and died gradually. However, only a smaller percentage of pineapple plants died from the pots treated with metalaxyl and 
fosetyl AL. We therefore recommend pre-plant treatment with metalaxyl and post plant treatment with fosetyl AL for the control of pineapple heart rot disease in Uganda. Further research needs to be

\section{Conflict of interest}

The authors have not declared any conflict of interests.

\section{ACKNOWLEDGMENT}

The facilities, permission and technical support provided by National Crops Resources Research Institute (NaCRRI), National Agricultural research Laboratories (NARL), Kyambogo University (KYU) and International Center for Tropical Agriculture conducted to determine the synergistic effect of metalaxyl and fosetyl AL and other pineapple agronomic practices in the control of pineapple heart rot disease in Uganda.

\section{Funding}

Fund for this study was a grant awarded to the second author by Regional Universities Forum for Capacity Building in Agriculture (RUFORUM) grant number- RU 2014 GRG- 085.

\section{REFERENCES}

Agrios, G. (2005) Plant Pathology. 5 ${ }^{\text {th }}$ edition. Elsevier Academic Press. San Diego, CA.

Bartholomew, D.P., Paul, R.E., Rohrbach, K.G. (2003). The pineapple: botany, production and uses. CABI Publishing, Wallingford, UK. pp 1-301.

Bua, B. Karungi, J. and Kawube, G. (2013). Occurrence and effects of pineapple mealy bug wilt disease in central Uganda. Journal of Agricultural Science and Technology, 3:410-416.

Cabral, J.R.S., Matos, A.P.d. and Coppens D'Eeckenbrugge, G. (1985) Segregation for resistance to fusariose, leaf margin type, and leaf colour from the EMBRAPA pineapple hybridization programme. In Martin-Prevel, P. and Hugon, R. (eds) Proceedings of the Second International Pineapple Symposium. Acta Horticulturae, Trois-Ilets, Martinique, pp. 193-200

Darwis, S.N. (1992) Phytophthora in relation to climate and coconut cultivar. Paper presented at the Coconut Phytophthora Workshop, Manado, Indonesia.

Drenth A, Sendall B, (2001). Practical guide to detection and identification of Phytophthora in Australia. CRC for Tropical Plant Protection, 2: $1-38$.

Drenth, A. and Sendall, B. (2004).Diversity and Management of Phytophthora in South East Asia by Australian Centre for International Agricultural Research (ACIAR).
(CIAT) are acknowledged by the authors. In a special way, we recognize the efforts put by Dr. Tusiime Geoffrey of Makerere University for his guidance on the experimental layout.
Erwin, D.C., and Ribeiro, O.K. (1996). Phytopthora Diseases Worldwide. St. Paul, Minnesota: American Phytopathological Society Press, country.

Farih, A., Tsao, P. H., and Menge, J.A. (1981).Fungitoxic activity of fosetylaluminum on growth, sporulation, and germination of Phytophthora parasitica and $P$. citrophthora Phytopathology 71:934-936.

Hassan, A., and Othman, Z. (2011) Pineapple (Ananas comosus L. Merr.). In: Elhadi M. Yahia (eds.), Postharvest biology and technology of tropical and subtropical fruits, Vol. 4.,Woodhead Publishing Ltd, UK,pp.104-212.

Hassan, R. E., Domokos-Szabolcsy. E., Abdalla, N.A., Taha, H.S., and Fári, M. (2015). Postharvest Management of Fruits and Vegetables Storage. In: E. Lichtfouse (ed.), International Journal of Phytopathology.

James. G. Scot .N. (2015) Heart and Root Rots of Pineapple. Published by the College of Tropical Agriculture and Human Resources. University of Hawii, Manao pp. 06

Jeffers SN, (2006). Identifying species of Phytophthora, Clemson University, USA. http://fhm.fs.fed.us/sp/sod/misc/culturi ng_species_phytophthora.pdf

Kwikiriza, N., J. Mugisha, P. Rye Kledal, K. Karatininis and C. Namuwooza. (2016). Tracing Uganda's global primary organic 
pineapple value chain. African Crop Science Journal, 24: 15.

Malézieux, E., F. Côte, and D.P. Bartholomew. (2003). Crop environment, plant growth and physiology. In D.P. Bartholomew, R.E. Paull, and K.G. Rohrbach (ed.) The pineapple: botany, production and uses. $\mathrm{p}$. 69-107. CABI Publishing, New York.

Matos, A.P.d. (2009) Doenças e seu controle. In: Cunha, G.A.P.d., Cabral, J.R.S. and Souza, L.F.S.d. (eds) O abacaxizeiro: Cultivo, agroindústria e economia. EMBRAPASCT, Brasilia, Brazil, pp. 269-305.

Mbaka JN, Losenge T, Waiganjo MM, Wamocho LS. (2010). Phenotypic variation in three Phytophthora cinnamomi populations from macadamia growing areas in Kenya. Journal of Animal and Plant Sciences, 8: 900- 911.

Mounde LG, Ateka EM, Kihurani AW, Wasilwa L, (2012). Morphological characterization and identification of Phytophthora species causing citrus gummosis in Kenya, AJFAND, 12(7)

Ocwa, A., B. Bua, J. Oculi and G. Tusiime. (2017) Morphological identification of phytophthora a causal organism of pineapple heart rot disease in Uganda.

Ocwa, A., B. Bua, J. Oculi and G. Tusiime. (2018) In vitro efficacy of fungicides for control of phytophthora nicotianae a causal organism of pineapple heart rot disease in Uganda. Direct Research Journal of Agriculture and Food, 6: 27-32.

Ocwa, A., Bua, B. Oculi, J. and Tusiime, G. (2017). Pathogenicity of pineapple heart rot disease causal organisms in Central Uganda. RUFORUM working document Series, 14(2):475-483.

Pegg, K.G. (1977) Soil application of elemental sulphur as a control of Phytophthora cinnamomi root and heart rot of pineapple. Australian Journal of Experimental Agriculture and Husbandry17, 859-865.

Py .C, Lacoeuilhe JJ, Teisson C (1987) The pineapple: cultivation and uses. Maisonneuve \& Larose, Paris. SB 111 A2 T4 No.37

Rodri'guez.Y. Mosqueda, M. ,Companioni.B., Arzola.B., Borras.O., Perez.m.C., Lorenzo.J.C., and Santos. R,(2002) Bioassay for in vitro differentiation of pineapple cultivar resistance levels to heart rot disease, Laboratory for Plant Breeding, Bioplant Centre, University of Ciego de Avila, 69450, Cuba

Rodríguez CJ, Nieto-Angel D, De León-García C, De Alba Ángel VM, Aguilar-Pérez LA, Ayala-Escobar V, (2015). Etiología de la pudrición del cogollo de la piña (Ananas comosus. L. Merril) cultivar MD2 en Isla, Veracruz.

Rodríguez, C. J., D. Nieto-Angel., C. De LeónGarcía, V. M. De AlbaÁngel., L. A. Aguilar-Pérez and V. Ayala-Escobar. (2015). Etiology of the heart rot of pineapple (Ananas comosus. L. Merril) MD2 cultivar in Isla, Veracruz, México. Revista Mexicana de Fitopatología, (1): 104-115.

Rohrbach KG, Leal F, Coppens d'Eeckenbrugge G (2003) History, distribution and world production. In: Bartholomew DP, Paull RE, Rohrbach KG (eds) The pineapple: botany, production and uses. CABI, Wallingford, UK, pp 1-12

Rohrbach, K.G. and Shenck, S. (1985). Control of pineapple heart rot, caused by phytophthoraparasitica and P.cinnamomi, with metalaxyl, FosetylAl and phosphorous acid, Plant Disease 69:320-323.

Saadoun M, Allagui MB. (2008) Pathogenic variability of Phytophthora nicotianae on pepper in Tunisia. Journal of Plant Pathology, 90: 351-355.

Shen,H.F, Lin,B.R, Zhan,J.X Pu,X.M.,(2013).First report of pineapple heart rot disease caused by Phythopthora nicotianae in Hainan province, China Plant Disease 974pp.560

Teshome E, Tegegn A (2017) Comparative Study of Powdery Mildew (Erysiphe polygoni) Disease Severity and Its Effect on Yield and Yield Components of Field Pea (Pisum sativum L.) in the Southeastern Oromia, Ethiopia. J Plant Pathol Microbiol 8:410. doi:10.4172/2157-7471.1000410

Uganda Investment Authority (UIA) (2015). Pineapple Production and Export Statistics, Annual Report, Kampala, Uganda, 2015. Pages/link

Uganda Investment Authority (UIA), (2008). Pineapple Production and Export Statistics, Annual Report, Kampala, Uganda, 2008. 